\title{
Reptiles of Fais Island, Yap State, Federated States of Micronesia ${ }^{1}$
}

\author{
Donald W. Buden ${ }^{2}$
}

\begin{abstract}
Eleven species of reptiles (six skinks, four geckos, one monitor lizard) are recorded from Fais Island, Micronesia, four of them (Gebyra mutilata, Lepidodactylus moestus, L. sp., and Eugongylus albofasciolatus) for the first time. The skinks Emoia caeruleocauda and E. jakati are the most common species; G. mutilata is the most common gecko in edificarian habitats, and L. moestus is the most common outside the areas of human habitation. Nearly all of the species are widespread in the western Pacific region, although Eutropis sp. is at the easternmost limits of its distribution in the Caroline Islands on Fais. The monitor lizard Varanus indicus was introduced during the Japanese administration. The other species may have arrived by natural dispersal, or by human assistance, or a combination of the two.
\end{abstract}

LitTLE IS KNOWN of the biota of Fais Island, Micronesia, and information on terrestrial vertebrates is especially scanty. Steadman and Intoh (1994) reported on the avifauna, focusing almost entirely on archaeological remains. Native mammals are absent, but Kramer (1937) recorded dogs (Canis familiaris) and rats (Rattus sp.), Intoh and Shigehara (2004) discussed the archaeological history of dogs and pigs (Sus scrofa) on the island, and Intoh (2008) commented further on dogs, pigs, and rats also from an archaeological perspective.

Information on the herpetofauna is almost entirely limited to Sternfeld's (1920) remarks on 44 specimens of five species of skinks and one gecko collected by E. Wolf on Feis (=Fais) in 1909, during the 1909-1911 Hanseatic South Seas Expedition. The names of six skinks are listed in the Sternfeld report, but Lygosoma sorex Boettger and L. kordoanum Meyer are synonyms of Emoia caeruleocauda (De Vis) (see Brown 1991). At least 40 of the 44 specimens are in the Senckenberg Museum,

\footnotetext{
${ }^{1}$ Manuscript accepted 4 July 2010.

${ }^{2}$ Division of Natural Sciences and Mathematics, College of Micronesia-FSM, P.O. Box 159, Kolonia, Pohnpei, Federated States of Micronesia 96941 (e-mail: don _buden@comfsm.fm).
}

Pacific Science (2011), vol. 65, no. 2:277-283

doi: $10.2984 / 65.2 .277$

(C) 2011 by University of Hawai'i Press

All rights reserved
Frankfurt, Germany (digital printout of collections, courtesy of G. Koehler and L. Acker). The only other mention of reptiles on Fais are passing remarks in several nonbiological articles alluding to a large lizard (referred to in one account as a monitor lizard), and almost certainly all pertaining to Varanus indicus.

This study was undertaken mainly to shed additional light on the distribution and relative abundance of reptiles on this remote and biologically poorly known Pacific outpost. The results of contemporaneous ancillary surveys of birds, butterflies, and dragonflies will be reported elsewhere.

\section{Study Area}

Fais $\left(9^{\circ} 46^{\prime} \mathrm{N}, 140^{\circ} 31^{\prime} \mathrm{E}\right)$ is a small (2.9 by $\left.1.2 \mathrm{~km}, 2.8 \mathrm{~km}^{2}\right)$, low $(28 \mathrm{~m})$ raised coral island in the west-central Pacific Ocean. It is approximately $210 \mathrm{~km}$ east of the main islands of Yap proper and $80 \mathrm{~km}$ east of Ulithi Atoll, which is the nearest land (Figure 1). Fais is a part of Yap State, within the Federated States of Micronesia (FSM), which includes (from west to east) Yap, Chuuk, Pohnpei, and Kosrae states. The FSM, together with the Republic of Belau (Palau) immediately to the west, make up the Caroline Islands. Topographically, Fais has a 100 to 150 m wide but discontinuous coastal belt that rises abruptly $(15-20 \mathrm{~m})$ in many places to a central plateau; shear cliffs rise directly out of the sea along 


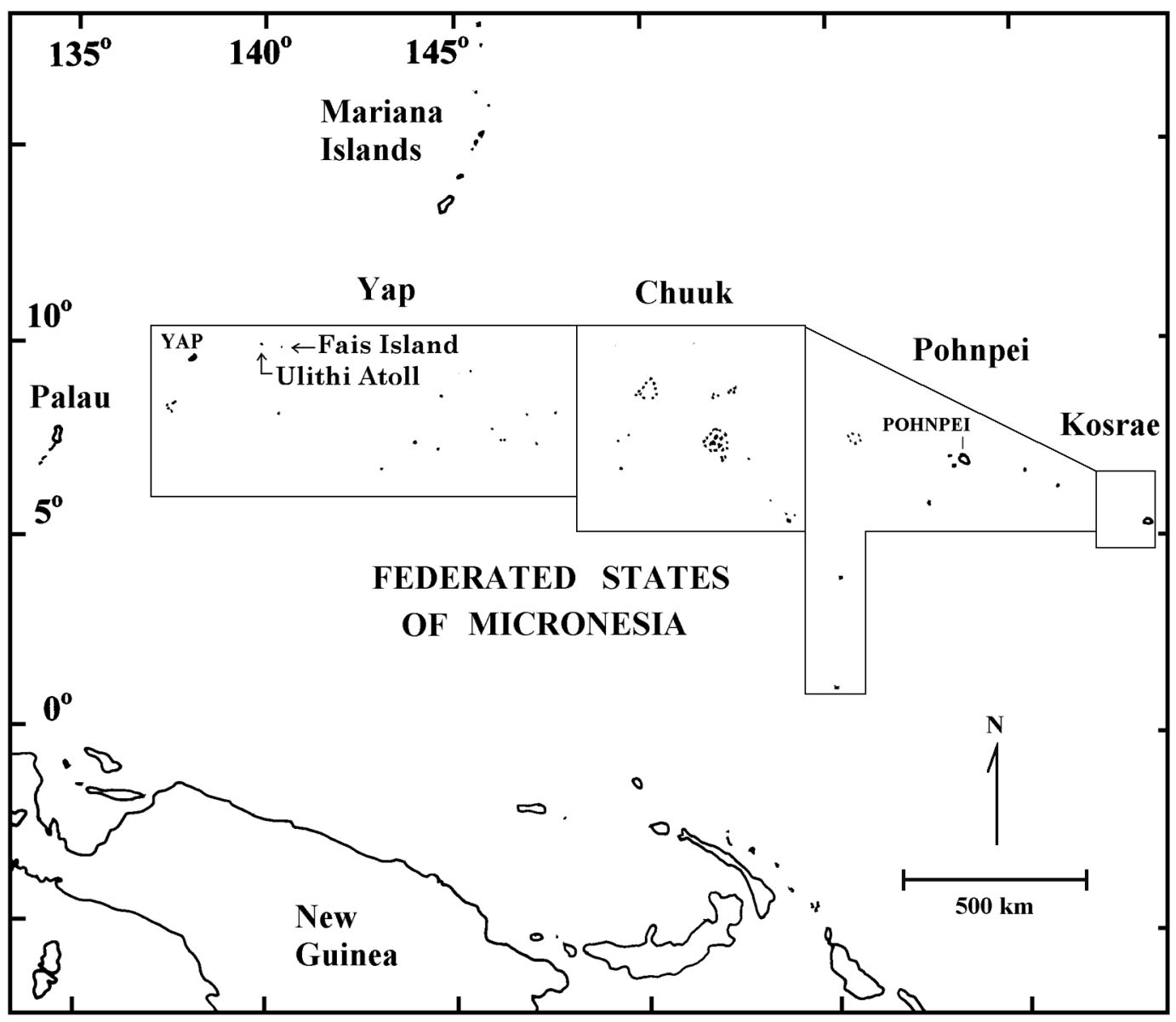

FIGURE 1. Location map for Fais Island and surrounding islands.

the northwestern and southeastern shores (Figure 2). Chamisso (1821:183) described Fais as having the most luxuriant flora of any island in the Carolines. However, much of the original forest and the face of the central plateau doubtlessly were decimated during extensive phosphate mining operations in the later years of the Japanese administration, from 1938 to 1944 (Intoh and Yamaguchi 1996). The forest has since been supplanted by scrub, secondary woodland, grassland, and farmland. Remnant forest dominated by Barringtonia asiatica is found mainly along the rim of the circumferential cliffs. A more detailed assessment of the flora and vegetation is provided by Fosberg and Evans (1969).

\section{MATERIALS AND METHODS}

Fieldwork was conducted during 17-21 December 2007 and 23-29 June 2009; 134 specimens of nine species of lizards were collected by hand and preserved. Most of the specimens were fixed in $10 \%$ formalin and later transferred to $35 \%$ isopropanol. Tissue samples, and in several instances whole specimens, of Emoia jakati, Eutropis sp., and Lepidodactylus spp. were preserved in ethanol for later DNA analysis. Specimens were deposited in the California Academy of Sciences; Museum of Comparative Zoology, Harvard University; National Museum of Natural History, Smithsonian Institution; and the U.S. Geological 


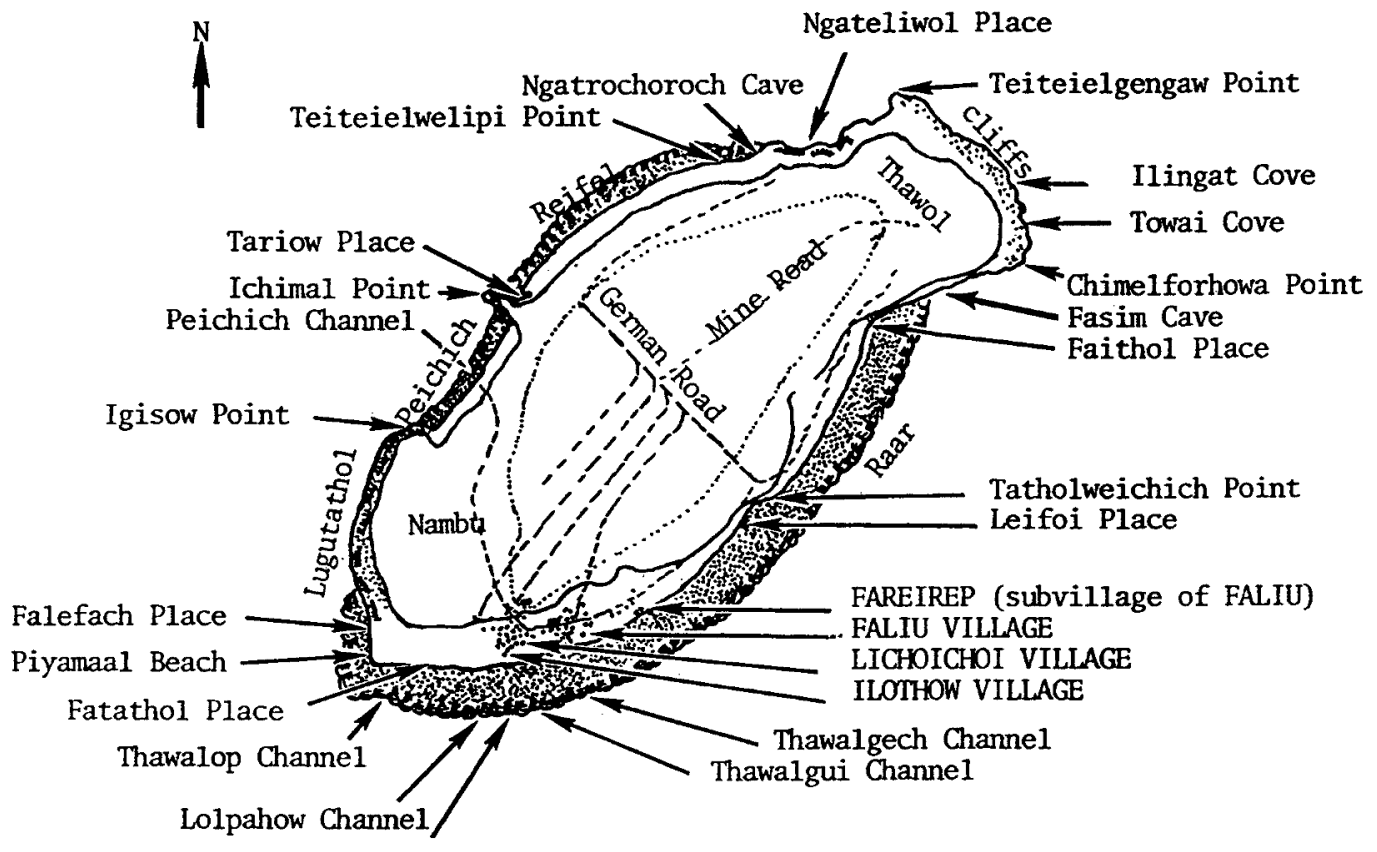

Thawos Channe1

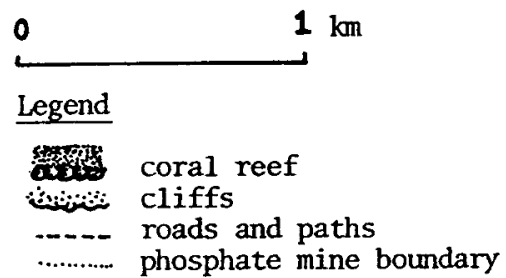

Figure 2. Fais Island localities (adapted from Gajdusek 1976).

Survey, San Diego Field Station. Terms of abundance are based on incidental observations and estimated encounters per day: common (at least 30 sightings per day under optimum conditions), fairly common (usually 5-15 per day), uncommon (1-5 on most days), scarce (fewer than four recorded sightings, all surveys combined).

RESULTS

\section{Geckos}

Gebyra mutilata (Wiegmann)

The stump-toed or mutilating gecko is common in edificarian habitats but scarce else- where. Of the 36 specimens collected, 35 are from buildings in the settlement and one is from a cliff face at the northern end of the island.

\section{Gebyra oceanica (Lesson)}

The oceanic gecko is fairly common throughout and found in a wide variety of habitats, including edificarian (mainly walls of buildings), forest (tree trunks), and scaevola shrubs along the beach.

\section{Lepidodactylus moestus (Peters)}

The Micronesian scaly-toed gecko is especially common in scaevola shrubs along the 
beach at night, where it was also the most abundant gecko during this study. It was also encountered regularly but somewhat less frequently in edificarian habitats and only occasionally in forest. Sixteen of the 19 examples of Lepidodactylus collected during this study are identified as L. moestus.

\section{Lepidodactylus sp.}

Three of the 19 specimens of the genus Lepidodactylus from Fais appear to be examples of an unidentified (and possibly undescribed) bisexual species other than L. moestus. They seem most similar to the undescribed sexual species from Palau (in Crombie and Pregill 1999) and to other specimens from Ngulu Atoll in southwestern Yap State (Fisher, pers. comm.).

\section{Skinks}

\section{Emoia caeruleocauda (De Vis)}

The Pacific blue-tailed skink is common throughout Fais. It was usually seen on the ground and 1-2 $\mathrm{m}$ high in weeds and shrubs and on tree trunks. Although some showed the typical color pattern of three pale dorsal stripes on a dark ground color, and juveniles had distinctly blue tails, many of the adults I observed were almost uniformly brown dorsally and had only a faint indication of stripes that were often reduced to a vestige of the middorsal stripe on the head.

\section{Emoia jakati (Kopstein)}

The Jakati skink is common in open, sparsely vegetated areas as well as in leaf litter on the forest floor. It was most numerous in coconut forest at the edge of the beach at Tariow Place (25 were counted in $5 \mathrm{~min}[300 / \mathrm{hr}]$ ), and others may have been present but could not be confidently distinguished from darkly colored E. caeruleocauda when glimpsed briefly.

\section{Eugongylus albofasciolatus (Günther)}

One reclusive litter skink that I observed at close range on the forest floor near the edge of the cliffs on the northwestern side of the island on 19 December 2007 is the only record. Identifying characteristics included its large size (snout-vent length $\sim 120 \mathrm{~mm}$ ), ro- bust body with a dorsal pattern of alternating dark brown and pale tan crossbars, short legs, and sinuous body movements. Eugongylus albofasciolatus is the only member of the genus documented in the FSM. However, Crombie and Pregill (1999) indicated that the genus is in need of review; species limits and their relationships remain largely unresolved.

\section{Eutropis sp.}

The taxonomic status of the lizards on Fais (and Ulithi Atoll) that Sternfeld (1920) recorded under Mabuia (=Mabuya) multicarinata is unresolved. Crombie and Pregill (1999) suggested that these Caroline Islands populations, together with those in Palau, may represent an undescribed species closely allied to $M$. multicarinata, and that they probably reached the Caroline Islands via natural dispersal from the Philippines and/or Borneo. In a recent revision of the genus Mabuya, Mausfeld et al. (2002) resurrected the name Eutropis Fitzinger for the Asia/Oceania species. A subsequent genetic study (Mausfeld and Schmitz 2003) supports the hypothesis that the Palauan population represents an undescribed species related to E. multicarinata, and that it probably colonized Palau by natural dispersal from the Philippines. The Fais/ Ulithi populations were not included in that study but are likely to fall within the Palauan group on geographic grounds.

Eutropis sp. is probably fairly common to common throughout Fais, though appearing scarce at times. I observed it in a wide variety of habitats, including grasslands, croplands, forest, coastal strand, and ruderal areas in the settlement. I saw no more than five or six (all presumed adults) during 17-21 December 2007, none of which I was able to collect. But I saw many more and collected 20 during 23-29 June 2009, including 11 juveniles, the smallest measuring $27.3 \mathrm{~mm}$ in snout-vent length and 10 others ranging from 30.9 to $34.6 \mathrm{~mm}$. Of the remaining nine specimens, one measured $58.4 \mathrm{~mm}$, and eight ranged from 64.1 to $74.2 \mathrm{~mm}$. Sternfeld (1920) recorded seven specimens collected during the 1909-1911 Hanseatic Expedition, the largest measuring $74.0 \mathrm{~mm}$. All those I encountered were very wary. The adults seldom allowed 
close approach and typically sought shelter under objects, or in holes in the ground or fissures in the rock face low on the cliffs when pursued; none climbed trees.

\section{Lamprolepis smaragdina (Lesson)}

The green tree skink is uncommon to fairly common throughout Fais and usually observed on tree trunks, less frequently in understory foliage, and rarely on the ground. Dorsal coloration was noted as olive green or grayish green in four specimens and brown in two, but incidental observations throughout the study suggest that brown is the predominant color in this island population.

\section{Lipinia noctua (Lesson)}

One male collected during the 1909-1911 Hanseatic Expedition (Sternfeld 1920) is the only record of the moth skink.

\section{Monitor Lizards}

Varanus indicus (Daudin)

Resident islanders told me that monitor lizards were introduced to Fais during the Japanese administration. Although Sternfeld (1920) remarked on specimens of $V$. indicus collected by the Hanseatic Expedition on Yap proper, there is no indication that the expedition encountered it on Fais. The earliest indication of $V$. indicus on Fais was provided by Keck (2004) in the memoirs of H. G. Turner, who, after having ditched a B-29 aircraft along the shore in November 1948, remarked on seeing "some large lizard-like animals that could climb trees." In addition, Gajdusek (1976:41), a medical doctor visiting Fais in 1964, remarked on seeing "a large greenish land lizard" called haluuf (the Yapese name for monitor lizard), and Rubinstein (1979) stated that local residents attributed the near disappearance of the Micronesian Starling from the island to predation by monitor lizards. I encountered approximately 5-10 monitors daily throughout the island, mainly on the trunks of coconut trees and on the forest floor, and less frequently on sandy beaches and rocky cliffs. Three were seen in repose on the paved airstrip on three separate occasions.

\section{DISCUSSION}

The herpetofauna of Fais includes at least 11 species of lizards (six skinks, four geckos, and one monitor lizard) (Table 1); no amphibians

TABLE 1

Status of 11 Species of Lizards Recorded from Fais Island, Yap, Western Caroline Islands

\begin{tabular}{|c|c|c|c|}
\hline Species & Status $^{a}$ & $\begin{array}{l}\text { Specimens } \\
\text { Collected }^{b}\end{array}$ & Principal Habitat(s) \\
\hline \multicolumn{4}{|l|}{ Geckos } \\
\hline Gebyra mutilata & $\mathrm{C}$ & $36 / 0$ & Edificarian \\
\hline Gebyra oceanica & $\mathrm{FC}-\mathrm{C}$ & $8 / 1$ & Edificarian/forest (tree trunks) \\
\hline Lepidodactylus moestus & $\mathrm{C}$ & $16 / 0$ & Scaevola shrubs \\
\hline Lepidodactylus sp. & S-UC? & $3 / 0$ & $?$ \\
\hline \multicolumn{4}{|l|}{ Skinks } \\
\hline Emoia caeruleocauda & $\mathrm{C}$ & $30 / 18$ & Forest floor/ruderal \\
\hline Emoia jakati & $\mathrm{C}$ & $14 / 6$ & Forest floor/ruderal \\
\hline Eugongylus albofasciolatus & $\mathrm{S}$ & $0 \% / 0$ & Forest floor? \\
\hline Eutropis sp. & $\mathrm{FC}-\mathrm{C}$ & $20 / 7$ & Forest edge/ruderal \\
\hline Lamprolepis smaragdina & $\mathrm{FC}-\mathrm{C}$ & $6 / 11$ & Tree trunks \\
\hline Lipinia noctua & $\mathrm{S}$ & $0 / 1$ & Cryptic? \\
\hline \multicolumn{4}{|l|}{ Monitor lizard } \\
\hline Varanus indicus & $\mathrm{FC}$ & $1 / 0$ & Forest \\
\hline
\end{tabular}

${ }^{a}$ C, common; FC, fairly common; UC, uncommon; S, scarce. See Materials and Methods for definitions of terms.

${ }^{b}$ This study (December 2007, June 2009)/the 1909-1911 Hanseatic Expedition (in Sternfeld 1920).

'No vouchers; single sight record only. 
or snakes are recorded. Resident islanders told me that turtles are encountered in the surrounding waters and that they occasionally come ashore, but there are no documented records.

Fais islanders claim that the monitor lizard, Varanus indicus, was introduced to the island in the early 1900s, during the Japanese administration, but the history of other species of reptiles is less certain. Some may have arrived by natural dispersal and others by human assistance beginning with the earliest aboriginal settlers and continuing to more recent times. Nine of the 11 species of lizards are widespread in the Caroline Islands and in many cases well beyond. The two others are undescribed species in the genera Lepidodactylus and Eutropis. The distribution of Lepidodactylus sp., and the extent to which it may be conspecific with other unidentified or undescribed populations in the Carolines, including those reported from Palau (Crombie and Pregill 1999); Ngulu Atoll, Yap (Buden 2010); and the Mortlock Islands, Chuuk (Buden 2007), is unknown. Eutropis sp., on the other hand, apparently has a very limited distribution in Micronesia, being known only from Palau (presuming conspecificity among the Carolines populations) and on Ulithi Atoll and Fais Island among the outer islands of Yap but not on Yap proper. It is apparently part of a Philippine radiation that may include several as yet undescribed taxa (Mausfeld and Schmitz 2003).

Among the species that are widespread and common (or at least locally common) in the FSM, but are unrecorded on Fais, are the geckos Hemidactylus frenatus, Lepidodactylus lugubris, Nactus pelagicus, and Perochirus ateles, and the skinks Emoia boettgeri, E. cyanura, and E. impar. To what extent these absences are real or are artifacts of limited sampling is uncertain and requires further investigation. The absence of the widely distributed adventitious species $H$. frenatus, however, is likely real inasmuch as it typically makes its presence known around lights at night wherever it occurs. Also, its absence on Fais is probably reflected in the abundance of Gebyra mutilata, which tends to be scarce or lacking where $H$. frenatus is well established (e.g., Buden 2007).

\section{ACKNOWLEDGMENTS}

I thank G. Koehler and L. Acker for providing information on specimens from Fais in the Senckenberg Museum, R. Fisher for contributing to the identification of specimens in the Lepidodactylus species complex and for reviewing a draft of the manuscript, and the Santus Saufar family for providing comfortable and pleasant living accommodations during my two visits to Fais.

\section{Literature Cited}

Brown, W. C. 1991. Lizards of the genus Emoia (Scincidae) with observations on their evolution and biogeography. Calif. Acad. Sci. Mem. 15:1-94.

Buden, D. W. 2007. Reptiles of Satawan Atoll and the Mortlock Islands, Chuuk State, Federated States of Micronesia. Pac. Sci. 61:415-428.

. 2010. Reptiles of Ngulu Atoll, Yap State, Federated States of Micronesia. Pac. Sci. 64:473-480.

Chamisso, A. von. 1821. A voyage of discovery, into the South Sea and Beering's Straits, for the purpose of exploring a North-East passage, undertaken in the years 18151818, at the expense of his Highness The Chancellor of the Empire, Count Romanzoff, in the ship Rurick. Vol. 3. Longman, Hurst, Rees, Orme, and Brown, London.

Crombie, R. I., and G. K. Pregill. 1999. A checklist of the herpetofauna of the Palau Islands (Republic of Belau), Oceania. Herpetol. Monogr. 13:29-80.

Fosberg, F. R., and M. Evans. 1969. A collection of plants from Fais, Caroline Islands. Atoll Res. Bull. 133:1-15.

Gajdusek, D. C. 1976. Journal of an expedition to the western Caroline Islands, $\mathrm{Au}-$ gust 26 to October 6 1964. Section of Child growth and development and disease patterns in primitive cultures, National Institute of Neurological Diseases and Blindness, National Institutes of Health. Bethesda, Maryland.

Intoh, M. 2008. Ongoing archaeological research on Fais Island, Micronesia. Asian Perspect. 47:121-138. 
Intoh, M., and N. Shigehara. 2004. Prehistoric pig and dog remains from Fais Island, Micronesia. Anthropol. Sci. 112:257-267.

Intoh, M., and Y. Yamaguchi. 1996. An analysis on historic photographs taken on Fais Island in Micronesia during the Japanese period. Hokkaido Tokai Univ. Bull. Hum. Soc. Sci. 9:37-63.

Keck, D. 2004. H. G. Turner: Hogan's Goat ditched at sea (www.angelfire.com/ia2/ hgturner/hgpost2.htm). Accessed 14 December 2010.

Kramer, A. 1937. Zentralkarolinen. I Halband: Lamotrek-Gruppe-Oleai-Fais. In G. Thelenius, ed. Ergebnisse der SüdseeExpedition, 1908-1910. II: Ethnographie, B. Mikronesien. Vol. 10, part 1. Friederichsen, der Gruyter \& Co., Hamburg.

Mausfeld, P., and A. Schmitz. 2003. Molecular phylogeography, intraspecific variation and speciation of the Asian scincid lizard genus Eutropis Fitzinger, 1843 (Squamata: Reptilia: Scincidae): Taxonomic and biogeographic implications. Org. Divers. Evol. 3:161-171.
Mausfeld, P., A. Schmitz, W. Böhme, B. Misof, D. Vrcibradic, and C. F. D. Rocha. 2002. Phylogenetic affinities of Mabuya atlantica Schmidt, 1945, endemic to the Atlantic Ocean archipelago of Fernando de Norhonha (Brazil): Necessity of partitioning the genus Mabuya Fitzinger, 1826 (Scincidae: Lygosominae). Zool. Anz. 241:281-293.

Rubinstein, D. H. 1979. An ethnography of Micronesian childhood: Contexts of socialization on Fais Island. Ph.D. diss., Stanford University, Stanford, California.

Steadman, D. W., and M. Intoh. 1994. Biogeography and prehistoric exploitation of birds from Fais Island, Yap State, Federated States of Micronesia. Pac. Sci. 48:116-135. Sternfeld, R. 1920. Zur Tiergeographie Papuasiens und der Pazifischen Inselwelt. Abh. Senckenb. Naturforsch. Ges. 36:375-436.

Turner, H. G. 2001. Uncle Sam-I'm back. B-29 Superfortress Then and Now Guest Column Archives: September 2001 (http:// home.att.net/ sallyann6/b29/hg-turner .html). 
